\title{
Scientific Basis of the Geoheritage and Geotouristic Values of the 641 AD Al Madinah Eruption Site in the Al Madinah Volcanic Field, Kingdom of Saudi Arabia
}

\author{
Mohammed R. Moufti ${ }^{1}$, Károly Németh ${ }^{*}, 1,2$, Hugo Murcia ${ }^{3}$, Sultan F. Al-Gorrry ${ }^{4}$ and \\ Jamal Shawali $^{5}$ \\ ${ }^{I}$ King Abdulaziz University, Geological Hazards Research Unit, Jeddah, Kingdom of Saudi Arabia \\ ${ }^{2}$ Massey University, Volcanic Risk Solutions, Palmerston North, New Zealand \\ ${ }^{3}$ School of Environment, The University of Auckland, Auckland, New Zealand \\ ${ }^{4}$ Saudi Commission for Tourism and Antiquities, SCTA Affiliate in Al-Madinah Province, Al Madinah, Kingdom of Saudi \\ Arabia \\ ${ }^{5}$ Saudi Geological Survey, Jeddah, Kingdom of Saudi Arabia
}

\begin{abstract}
Recent volcanological and volcanic hazard studies on the youngest volcanic fields in the western Arabian Peninsula, such as the Al Madinah Volcanic Field (AMVF) in the Kingdom of Saudi Arabia, resulted in the systematic evaluation, characterization and recording of their volcanic geoheritage. The two youngest volcanic eruptions of the AMVF were in $641 \mathrm{AD}$ and $1256 \mathrm{AD}$, as documented in historic records. Both eruption sites are located nearby the holy city of Al Madinah and therefore offer a unique opportunity to develop geoheritage, geoconservation and geotourism projects. Here we present geological evidence to justify the location of a visitor and education center at the 641 AD eruption site, a future gateway to the proposed Al Madinah Volcanic Geopark. The inferred location of the 641 AD eruption consists of four cones that are located in a suburban area of Al Madinah city, outside of its "haram" area (an area restricted for Muslims only). The four cones formed through a broad array of volcanic processes that represent a complete spectrum of the volcanic processes recorded in the whole AMVF. Here we provide a detailed description of the volcanic features of these four cones and contrast these features with the broader volcanic heritage of the AMVF to provide a strong scientific basis to the establishment of a visitor and geoeducation center in the vicinity of these four cones. We also provide some basic data on the potential benefit and touristic value of such a project as a potential gateway to the newly proposed Harrat Al Madinah Volcanic Geopark.
\end{abstract}

Keywords: Geotourism, geopark, geoheritage, geoconservation, volcanic eruption, Islamic culture, Arabian Peninsula, Middle East.

\section{INTRODUCTION}

Recent scientific work on volcanic fields in the western part of the Kingdom of Saudi Arabia clarified our understanding of the volcanism that occurred in the last 30 million years in the Arabian Peninsula. Such research has been intensified recently due to an earthquake swarm in the year 2009 close to the Red Sea coastline, which was inferred to be the result of newly intruding magmatic bodies that arrested at a shallow level $[1,2]$. While a volcanic eruption did not occur in this time, the event itself highlighted the need to investigate the volcanism in this region further, applying modern techniques and systematic studies along the volcanic fields parallel to the Red Sea coast. As well as advancing our knowledge of the volcanism and volcanic processes, this recent research has provided [3-6] a scientific

*Address correspondence to this author at the Massey University, CS-INR, Volcanic Risk Solutions, Turitea Campus, Palmerston North, New Zealand; Tel: +64-27-479-1484;

E-mails: k.nemeth@massey.ac.nz, knemeth@xtra.co.nz basis for the application of volcanic hazard assessments, as well as for natural hazards education. In addition, a "byproduct" of the volcanology and volcanic hazard studies has been the systematic evaluatation, characterization and recording of the volcanic geoheritage of these volcanic fields. This information can be built in to a repository of volcanic geological features significant on the national, as well as in international, level [7-9], in a similar way to other successful geoparks or geoheritage projects [10-14]. Such initiatives are very recent in the Kingdom of Saudi Arabia, and therefore it is considered to be an emerging research subject in the Kingdom.

One of the key volcanic locations of western Saudi Arabia is located nearby the holy city of Al Madinah, where over 500 volcanic cones and lava fields are spread over an area of $60000 \mathrm{~km}^{2}$ formally named as the Harrat Al Madinah [3]. Traditionally the lava flow dominated fields are defined as "harrat" referring to an Arabic word in the possessive form of the singular noun "harra", which means "stony area, volcanic country, lava field" [15]. It is related to 
the adjective "harr", meaning "hot" (cross-referenced from Camp and Robol 1989).

The Harrat Al Madinah is the northern part of the Harrat Rahat. The Harrat Rahat is a stratigraphically overlapping array of volcanic fields that were active in the past for about 10 million years, leaving behind at least four stratigraphy units of volcanic rocks as a result of a slowly northward shifting eruption locus of magmatism [3, 6, 16]. The youngest volcanic events produced the Harrat Al Madinah or AMVF that is inferred to be formed since $1.7 \mathrm{Ma}[3,6,16]$. The two youngest volcanic eruptions in these regions have been documented in historic records and were recorded in $641 \mathrm{AD}$ and $1256 \mathrm{AD}$ (Fig. 1) [16]. While the location of the $1256 \mathrm{AD}$ eruption is fairly well-established, the location of the $641 \mathrm{AD}$ eruption is somewhat ambiguous [16]. The 1256 $\mathrm{AD}$ eruption took place about $20 \mathrm{~km}$ from the center of the city (Fig. 1) [17]. Geological evidence indicates that the likely location of the $641 \mathrm{AD}$ eruption is a chain of four small volcanic cones located about $12 \mathrm{~km}$ from the city center (Fig. 1) [16, 17]. These cones are located in a suburban area of Al Madinah city, outside of its "haram" area, and therefore it is accessible for both Muslims and nonMuslims (Fig. 1). The four cones can be accessed via good infrastructure linked to main highways entering the city (Fig. 1). The area is currently public land, used for small-scale community rubbish disposal damping and excavating small volumes of raw material for construction purposes. The four cones form a $2.3 \mathrm{~km}$ long volcanic chain (Fig. 2A) in the suburban territory and completely surrounded by wide sealed roads with extensive parking areas, making the site a perfect location for geoheritage and geotourism projects.

Intracontinental volcanic fields, such as the Al Madinah Volcanic Field (AMVF), are widespread volcanic features on Earth and other planets [18] and they host the most common volcanic landforms on Earth, including scoria (cinder) cones, tuff rings, maars, lava flows and lava lakes [19, 20]. The eruption style and architecture of these volcanoes commonly see them classified as "monogenetic" to express their short eruption duration, as well as the distinct and dispersed nature of the volcanic vent formation associated with them [21]. A consequence of monogenetic volcanism is that they form volcanic landforms that are "human-scale" in size and provide a broad array of volcanic features to be studied and visited in an often fairly easy to access way. Such natural settings make monogenetic volcanoes and volcanic fields perfect geoeducational sites with a strong geotouristic emphasis to use the areas to contribute to local economy growth and public awareness. New advances in understanding the evolution of intra-continental monogenetic fields, such as those in the western Arabian Peninsula, have put this type of volcanism at the front-line of volcanic research globally over the past decades [22, 23].

With the growing population on Earth, it becomes increasingly important to develop geoeducational programs in these regions and others to disseminate our current understanding of this type of volcanism, with an aim to pass on information about potential eruption scenarios, volcanic hazards, and available volcanic crisis management to the general public [24]. In volcanic areas where volcanic eruptions occurred many generations ago, but the area is still considered to be active, such geoeducation projects are particularly important in respect to increasing the knowledge and awareness of the general public about volcanism and its influence on the environment and human society.

The Kingdom of Saudi Arabia is a region where large areas of land are volcanic fields that have been active in the past 10 million years [5, 16, 25-28], leaving behind nearly every volcanic feature possible in a dispersed intracontinental volcanic field (Fig. 1). These regions have not experienced a volcanic eruption since the 1256 AD Al Madinah eruption [17] and therefore geoeducation projects could be vital in demonstrating the causes and consequences of volcanism for the general public.

The four cones of the $641 \mathrm{AD}$ eruption - the subject of this paper - formed through a broad array of volcanic processes that represent a near-complete spectrum of volcanic eruption styles, eruptive products and volcanic landforms recorded elsewhere in the whole AMVF. These include scoria cone-forming eruptions, lava spatterproducing lava fountaining, small-volume lava dome intrusions, partial cone collapse due to rafting and emplacement of short lava flows, many of them with clastogenic origin [9]. The volcanic geology of the four cones of the 641 AD eruption effectively "mimics" nearly every volcanic feature one can visit in the whole AMVF. The 641 AD four cones, therefore, offer an easy access location in the city of Al Madinah that can be aided by a provisional educational center and associated geoeducation projects that eventually could play a major role in the development of the earlier proposed Harrat Al Madinah Volcanic Geopark [9].

Here we provide a detailed description of the volcanic features of these four cones and contrast these features with the broader volcanic heritage of the AMVF [9] to provide a strong scientific basis for the establishment of a visitor and geoeducation center in their vicinity. Establishment of volcanic geoparks and associated geoconservation and geotouristic projects are heavily reliant on the scientific and educational foundation of the proposed projects in concert with detailed assessments of the local and regional benefits of such projects [29-33]. Geotourism and its facilitators, geoparks, are commonly viewed as the gateway of socioeconomic development of a region, particularly rural or underdeveloped areas [29, 34]. After providing supporting evidence to justify the geologically unique features of the $641 \mathrm{AD}$ eruption site, we also provide some basic data on the potential benefit and touristic value of such a project as a potential gateway to the newly proposed HAMVG project.

\section{HIERARCHIC VOLCANIC PRECINCT CONCEPT OF THE RECENTLY PROPOSED HARRAT AL MADINAH VOLCANIC GEOPARK}

The proposed Harat Al Madinah Volcanic Geopark (HAMVG) (Fig. 1) is based on a holistic geoeducation and geoconservation philosophy in order to demonstrate the diversity of volcanism associated with the evolution of longlived monogenetic volcanic fields in intra-continental regions [9].

The suggested hierarchical arrangements of the volcanic features and landforms preserved in the territory of the 


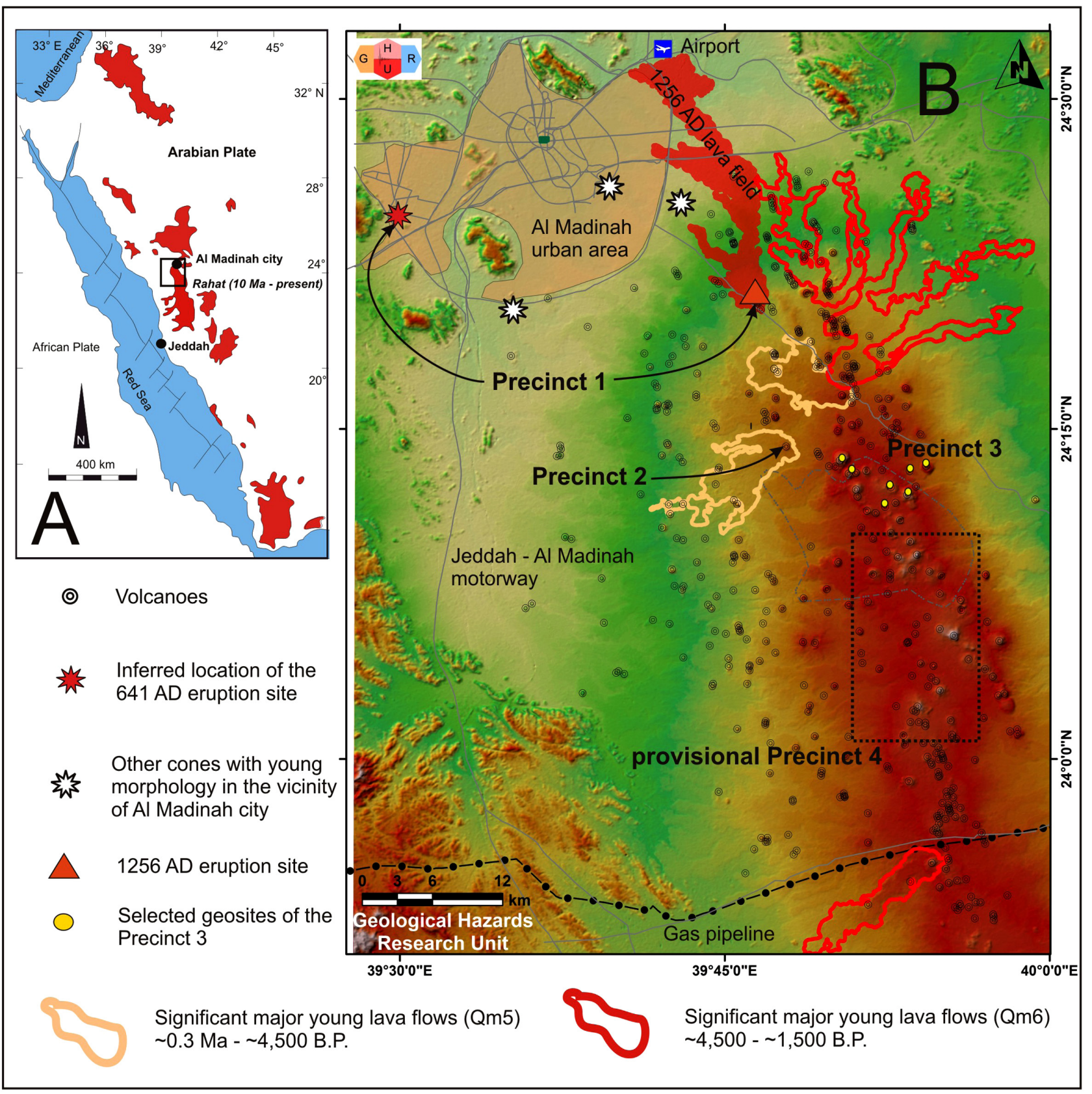

Fig. (1). (A) Overview map of the location of harrats in the Arabian Peninsula. (B) Overview map of the Harrat Al Madinah showing the main geoheritage precincts, young lava flows and the inferred location of the $641 \mathrm{AD}$ eruption site in relation to the city center of $\mathrm{Al}$ Madinah. Major young lava flows are marked on the map following their stratigraphy distinction. Age data and stratigraphy unit names are based on "Moufti MR, Moghazi AM, Ali KA. 40Ar/39Ar geochronology of the Neogene-Quaternary Harrat Al-Madinah intracontinental volcanic field, Saudi Arabia: implications for duration and migration of volcanic activity. Journal of Asian Earth Sciences 2012; 62: 253$268 "$ ".

proposed HAMVG will emphasize the scientific (geological - volcanological) entity, the level of importance, and access to those sites to be able to fit geoconservation, geoeducation and geotourism projects based on the volcanic field's natural setting [9]. Geological (and/or geomorphological) sites have just been started to be catalogued following the geosite (geomorphosites), geotop and geopark concept that has been successfully used elsewhere [30, 35-37]. Recently initiated projects in the Kingdom of Saudi Arabia have identified and documented many volcanic geosites that are significant in their context, such as significant in comparison to the host volcanic region where they are located, as well as carrying values that make them internationally important volcanic features to contribute to the global understanding of specific volcanic processes [7]. In the first proposal to establish a geopark in the Al Madinah Volcanic Field, a well-designed 

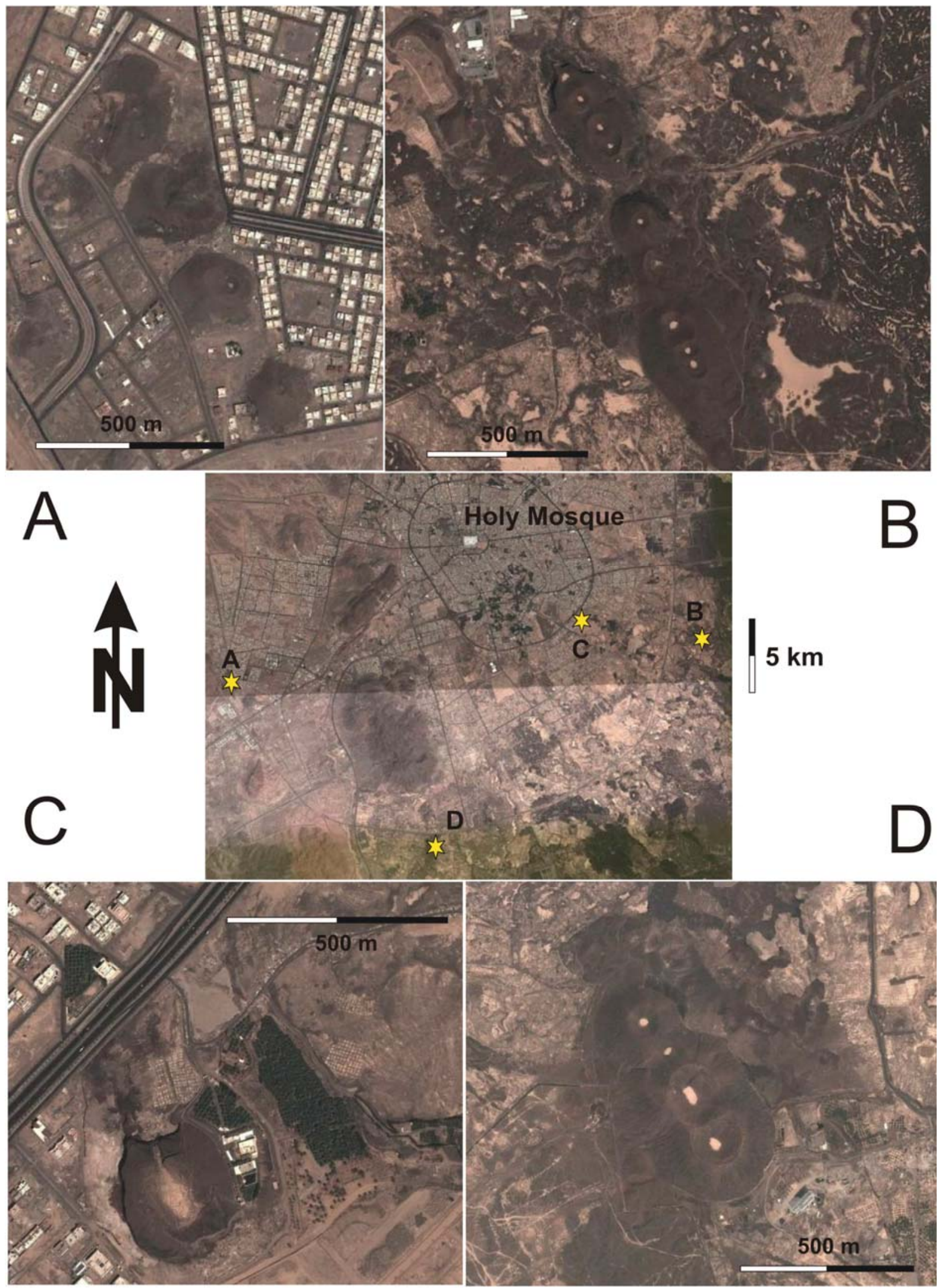

Fig. (2). Google Earth images of young scoria cones located in the vicinity of Al Madinah urban area. All the maps oriented toward North. (A) Alignment of the four cones inferred to be the source of the $641 \mathrm{AD}$ eruption. (B) Young scoria cones front of a plane of the $1256 \mathrm{AD}$ lava flows. (C) Individual scoria cone close to Al Madinah city centre sitting on and surrounded by older lava flows. (D) Chain of scoria cones in the southern margin of Al Madinah city. 
volcanic geological model was used to distinguish volcanic areas that can be linked together along scientific reasons, as well as landscape aesthetic and accessibility values [9]. This new geoconservation, geoeducation and geotourism design was based on the so called "precinct" concept that naturally groups together the main and most representative volcanic features (including landforms and associated geotops) to form three distinct precincts as the basis of a proposed volcanic geopark [9]. The HAMVG's volcanic landforms fit naturally in to this three-layered precinct hierarchy, which has been successfully applied to geoparks elsewhere, including the Kanawinka Geopark in southern Australia and Victoria (http://www.kanawinkageopark.org.au/). In comparison to the Kanawinka Geopark's precincts, the proposed HAMVG's precincts are not only thematically but also geographically well-separated, allowing distinct geotoursm projects to be designed around them [9]. The HAMVG three precincts are proposed as:

Precint 1) Historic Eruption Precinct - 1256 AD and 641 AD Historic Eruption Sites;

Precinct 2) Lava Lakes, Lava Fountains and Volcano Spreading Precinct - The Mosawdah Volcano and

Precinct 3) From Silicic Lava Domes to Explosion Craters Precinct [9].

Precinct 1 groups volcanic features and associated geoeducational and geotourism programs that demonstrate the eruption sites that have been historically documented and are probably the most relevant to the inhabitants of $\mathrm{Al}$ Madinha city. This precinct hosts numerous geosites dealing with extensive transitional pahoehoe-to-aa lava fields with world-class examples of lava flow surface textures, lava spatter and scoria cone [7]. Precinct 2 can be viewed as an expansion of the first, offering the visitor a more in-depth understanding of the type of volcanism very common in the Harrat Al Madinah. This geosite is more difficult to access than Precinct 1 and would involve some "adventure tourism" style trip which makes this precinct available only to those visitors who wish to go deeper in to understanding volcanic processes. Precinct 1 and 2 fundamentally cover the majority of the volcanic features that can be located in the Al Madinah Volcanic Field. Precinct 3 offers the most adventurous trips for visitors and some unique additions to understanding the full spectrum of volcanic processes in the AMVF. Precinct 3 volcanic features deal with silica-rich volcanism that formed various lava domes (e.g. trachytic), as well as deep explosion craters, many of them at least in their initial phase were formed due to magma and ground-water explosive interaction. Precinct 3 is located far from Al Madinah city, and only well-equipped geotourists with trained guides can visit the sites. While the volcanic features in Precinct 3 can be seen to have a very high aesthetic and scientific value, they are rather an extra addition to the full picture of the volcanism of the AMVF, than something without which the visitor would get a distorted image of the field. However, those who decide to invest energy to visit Precinct 3 would be well rewarded by a truly dramatic volcanic landscape. Precinct 3 could be expanded toward the south (provisional Precinct 4) as an alternative geoheritage site, where a great variety of pyroclastic flow deposits and associated volcanic craters can be visited. These sites have a very unique landscape value. However, visits to these sites can only be done by well-prepared adventure tours (Fig. 1).

\section{THE 641 AD AL MADINAH ERUPTION GEOTOPE}

The eruption site of the historically documented $641 \mathrm{AD}$ volcanic eruption has been determined by a combination of historical, as well as geological, data (Fig. 2A). Historical records report a short-lived volcanic eruption in $641 \mathrm{AD}$ that was located in the vicinity of the ancient city of Al Madinah. Indirect references to the volcanic unrest gave some controversial data on the location of the eruption, putting it in the SE side of the city. A brief description of the $641 \mathrm{AD}$ eruption is given in an Arabic book "Wafa Al-Wafa Bi'Akhbar Dar Al-Mustafa" written by Nooruddin Ali Bin Ahmed Al-Samhoodi [38]. The description states that during the reign of the second Rashidi Khalifah Omar bin AlKhattab (13-23 A.H. [Hijri Calendar] - 634-644 A.D. [Gregorian Calendar]), a small fire rose from Harrat Al Madinah and soon died out; this has subsequently been interpreted as a volcanic eruption. Other short descriptions indicate that the eruption must have not been too far from the city center, and it was probably visible, at least in the night. Al Madinah city is located in a basin (Fig. 1) that is filled with thick alluvial deposits derived from the higher basement rocks standing as horst blocking the western and northern side of the basin. Toward the south and east, lava fields (harrat) sitting on faulted Precambrian blocks forming a distinct morphologically elevated zone about at least 15 kilometres from the city center (referred to here as the location of the Holy Mosque). Distal lava flows located along the present outer city limit of Al Madinah are inferred to represent lava flows initiated from unknown sources in the northern part of the AMVF (Fig. 1). In the basin of Al Madinah, four distinct scoria cones can be identified, each sharing a common young morphological feature and each considered to be a good candidate to be the source of the historically recorded $641 \mathrm{AD}$ eruption sites (Fig. 1). From these four volcanic cones (or groups of cones) two can confidently be discarded as "candidates" based on relative stratigraphy to older lava flows [39] that are seemingly diverted by the presence of the cones (Fig. 2B, C). A single scoria cone that is about $6 \mathrm{~km}$ from the city center and heavily quarried is more difficult to discard as potential candidate source of the $641 \mathrm{AD}$ eruption; however, the geological mapping assigned a relatively old age to this cone, based on its stratigraphic relationship to a nearby old lava flow horizon [39] (Fig. 2D). The only site, where unfortunately there is no independent stratigraphic data to constrain its relative stratigraphy, is a chain of four small volcanic cones located in the SW part of the basin of $\mathrm{Al}$ Madinah about $12 \mathrm{~km}$ from the city center (Fig. 2A). These cones are sitting on a young alluvial plain filled with gravelly debris derived from the elevated Precambrian basement blocks (Fig. 3). These four cones have young volcanic morphology (eg. steep cone flanks, near angle of repose slope, intact crater rim, limited gully formation on its outer flank) that is suggestive of their young eruption ages, when their geomorphology features are compared to other young cones elsewhere [40, 41]. However, these cones are located behind a ridge preventing their direct view from the city center (Fig. 1). Nevertheless, in case of a volcanic eruption, these cones could have also been visible for 


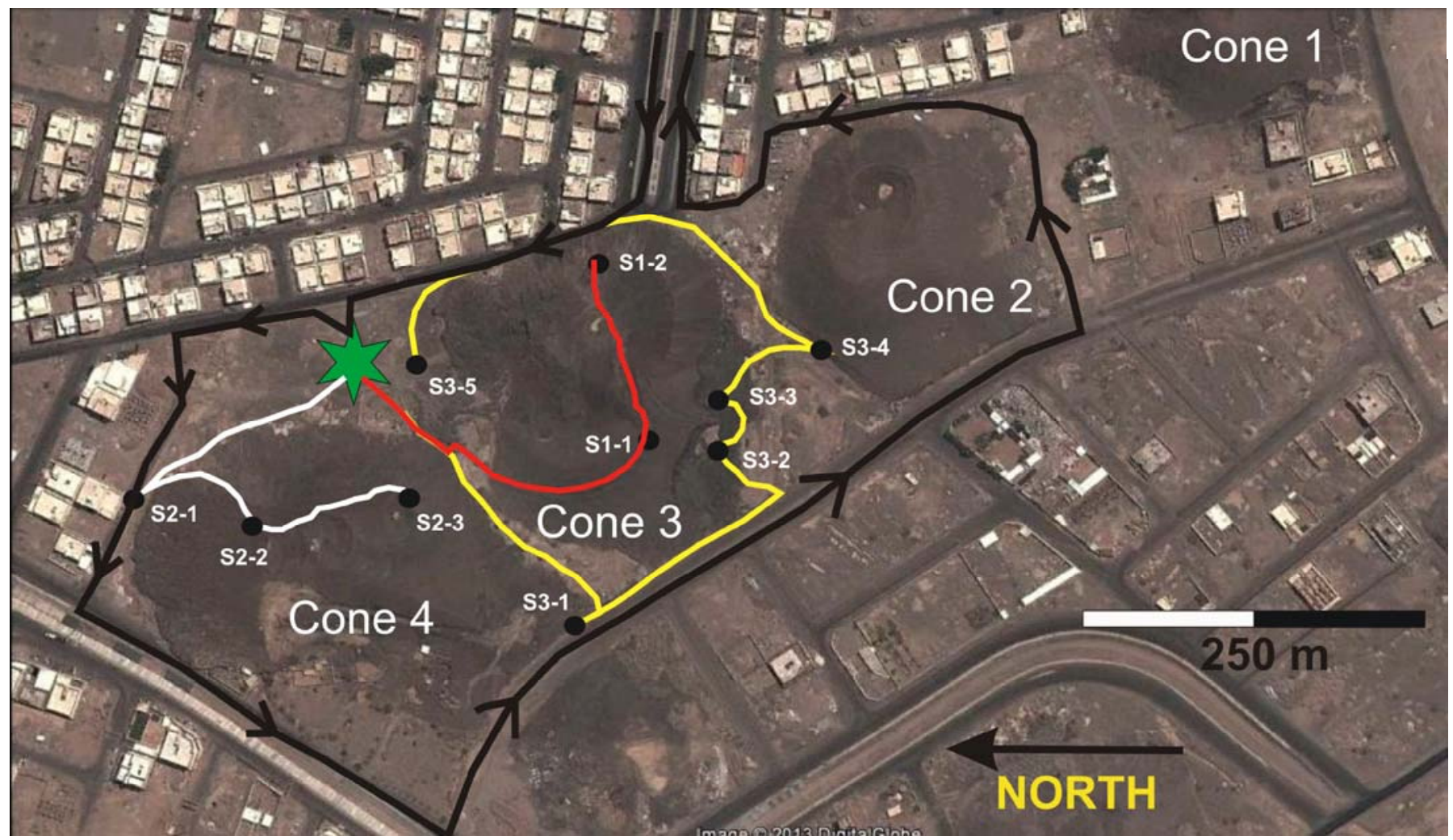

Fig. (3). Close up view of the $641 \mathrm{AD}$ scoria cones. Note that the image left side points toward north. Star represents potential visitor centre location. Black line with arrows represents road network the site can be accessed by car. Study path 1, 2 and 3 marked with different colours such as red, white and yellow respectively. Points of interests are marked along the study paths.

watchman guarding the entry roads lead to Al Madinah, and/or by eruption columns (lava fountains, Strombolian explosive bursts) that lit up the night sky and/or reached higher elevations (about more than 500 metres), allowing direct visibility from the city center. On the basis of the above outlined logic, these four cones have been suggested and widely accepted as the source of the 641 AD eruption $[17,39]$, and in this paper we also treat them as the most likely location of this eruption.

\section{VOLCANIC GEOSITES OF THE MOST LIKELY LOCATION OF THE 641 AD ERUPTION}

The four cones inferred to be the source of the $641 \mathrm{AD}$ eruption host numerous geosites that are representative of the majority of the volcanic eruption styles, volcanic landforms and volcanic processes associated with and/or responsible for the volcanic evolution of the AMVF. For clarity, we refer to cone 1 as the southernmost located cone, and cones 2, 3 and 4 refer to the other cones toward the north (Fig. 3). The four distinct and well-preserved cones form an about $1.1 \mathrm{~km}$ long chain (from the base of the northernmost to the base of the southernmost cones) aligned to a direction of 335 degrees $(\sim \mathrm{NNW})$. Each of the four cones is similar in size, with a base diameter of about $200-250 \mathrm{~m}$ and relative heights of about $30-50 \mathrm{~m}$. The tallest but the simplest volcano is the most southern (cone 1) and is composed of a conical shape edifice with an enclosed single crater (Fig. 4A). The other three cones are somewhat more complex and exhibit multiple craters and complex volcanic stratigraphy, ranging from a basal tuff ring (Fig. 4B) abundant in accidental lithic fragments commonly cored in lapilli and bombs (Fig. 4C) to various types of scoria cones, lava spatter cones, small lava coulee and short lava flows (Fig. 4D). From a volcanic hazard point of view, cones 2,3 and 4 are the most interesting because each of them has a basalt tuff ring. The thinnest tuff ring sequence can be seen at cone 2, while cones 3 and 4 have about $5 \mathrm{~m}$ thick succession of lapilli tuff that is inferred to have formed by an initial explosive eruption triggered by the interaction of rising basaltic magma and the shallow ground-water table $[42,43]$ and the resulting pyroclastic rocks are defined as a basal phreatomagmatic succession (Fig. 4B). While the preserved pyroclastic succession is relatively thin (about $5 \mathrm{~m}$ ), the exposed section is significant because this is the only place so far in the AMVF where evidence of magma-water explosive interaction in the early stage of scoria cone formation is recorded (Fig. 4B). While phreatomagmatism is inferred to be the cause of the initial explosive, vent opening stage in many older $(0.3-0.7$ Ma old) volcanoes located in Precinct 3 (far from Al Madinah city) in the HAMVG, such records in association with small basaltic volcanoes are not known in the vicinity of Al Madinah city, especially not in other young or historic eruption sites. The basal tuff ring deposits also expose numerous cored bombs (Fig. 4C) that are the spectacular results of the interaction between cold country rocks and low viscosity basaltic magma, capable of engulfing particles and being ejected as a cored bomb [44, 45]. The fact that three out of the four cones have a basal tuff ring indicates that during this eruption, at least in their initial phase, magma interacted with shallow ground-water and triggered base surges that accumulated a relatively thin tephra unit (Fig. 4B). This also indicates that, if a future 


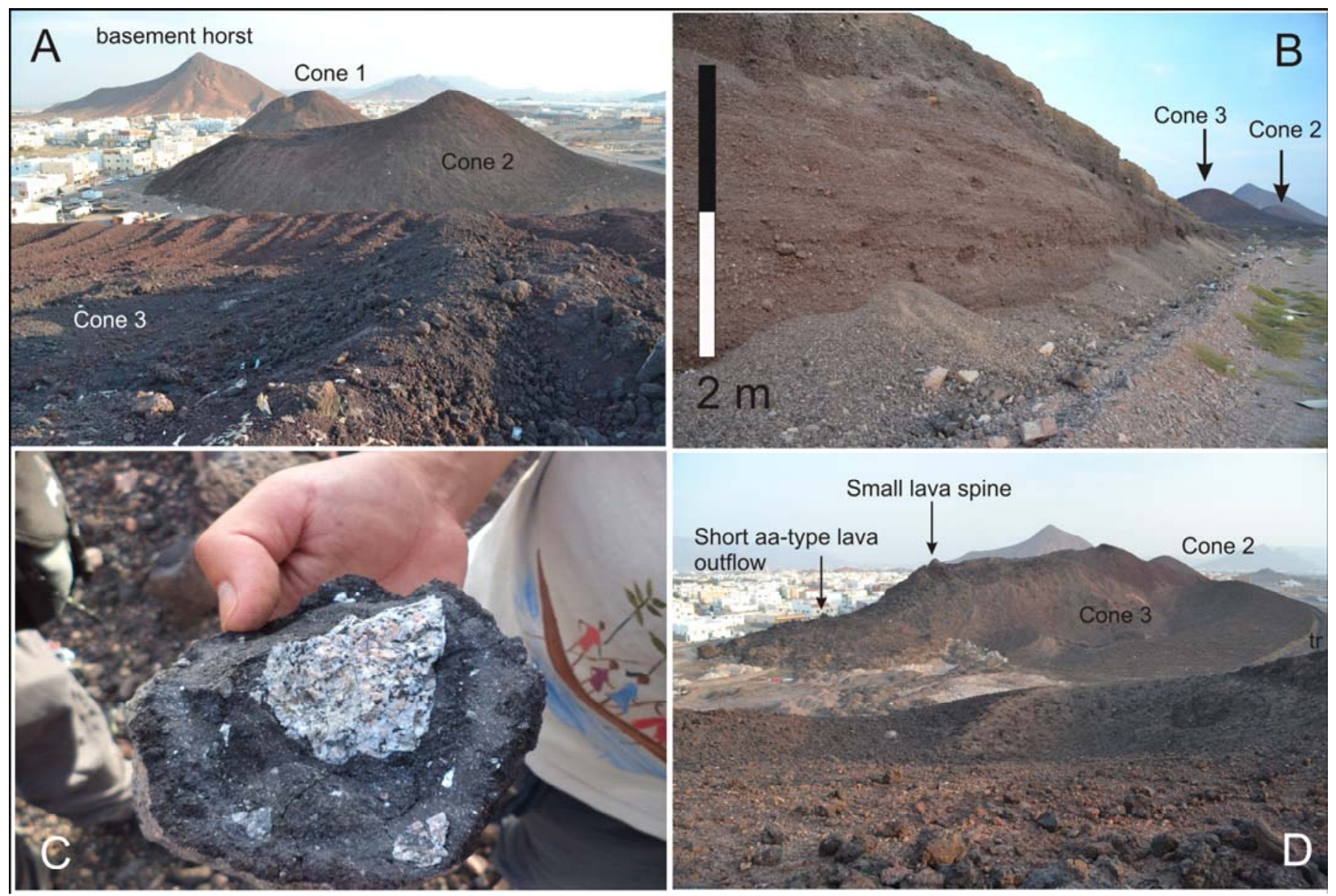

Fig. (4). (A) View toward the south of the volcanic chain located in the urban area of Al Madinah city. (B) Basal pyroclastic succession exposed in the base of Cone 4 representing deposits formed due to phreatomagmatic explosive eruptions. (C) Cored bomb with crustal rock fragments abundant in the basal phreatomagmatic successions of the 641 AD volcanoes. (D) Overview of Cone 3 with a small lava spine and short lava outbreak toward the east.

eruption would take place in the area of the Al Madinah basin, there is a chance that the initial stage of the eruption could be phreatomagmatic. This easy to access location, therefore, can demonstrate a fundamental eruption process that has a strong implication to understand the volcanic hazard a future volcanic eruption could pose to the city of Al Madinah. This fact enlarges the educational, and perhaps the geotouristic value, of this site, as well as demonstrating the uniqueness of the location itself. The fact that the only other volcanic successions recording phreatomagmatism are located far from the city elsewhere in the AMVF (Precinct 3 ), means that developing geoeducation projects and fitting them to geotourism programs at the $641 \mathrm{AD}$ site would be very beneficial in terms of disseminating scientific information to the general public and demonstrating the full array of volcanic processes this type of volcanism can produce. Following the previous logical argument, particularly cone 3 and 4 are ideal sites to provide descriptive information and geoeducational projects to demonstrate the variability that can be produced by scoria cone and lava spatter cone eruptions.

At cone 3 the basal phreatomagmatic succession is covered by a black scoria unit that gradually evolves from the basal phreatomagmatic unit, indicating that the eruption was gradually shifted from a phreatomagmatic to magmatic explosive eruption style. Similar sections are well known from other protected geosites that are part of geoeducational and geopark programs, like those in the Eifel Vulkanpark in Germany, such as the Rothenberg scoria cone [46]. Cone 3 also hosts a well-developed lava spatter cap that is connected to a small lava spine and short but thick lava flow. Cone 4 shares many similar features to cone 3 . Cone 4 , however, has a slightly longer lava flow that is partially fed from lava fountains. Subsequent explosive eruptions produced large spindle bombs that litter the surface of the short lava flow that reached about 150 metres from its vent. Both cone 3 and 4 show some evidence of lava cone rafting that gradually opened the cones toward the north. In summary, the 641 AD eruption site offers nearly every possible volcanic feature to visit, observe and walk on that otherwise would only be possible if the visitor were to spend time travelling outside of the town to the distant parts of the HAMVG.

\section{JUSTIFICATION OF THE SIGNIFCANCE OF THE 641 AD ERUPTION SITE}

While there is no doubt that the most complete picture a visitor could get on the historic eruptions of the AMVF is to visit the 1256 AD Al Madinah Volcanic Geotope [9] which offers excellent individual volcanic geosites to promote volcanological knowledge on the evolution of a fissure-fed 
lava fountain-dominated volcanic eruption. However, such visit to this location would involve an immediate effort from any visitor and by completing the designed walks to explore the $1256 \mathrm{AD}$ eruption site would certainly fall in the category of adventure tourism. The 641 AD eruption site, however, can immediately provide an easy access location where the results of every known volcanic process identified in the AMVF are ready to visit, experience and study. This is an immediate and highly valuable advantage of the $641 \mathrm{AD}$ eruption site over any other sites in the AMVF. In addition, this natural setting lends itself to the investment of funds, energy and time to develop scientifically well-established programs to develop this site as a gateway to the Harrat Al Madinah Volcanic Geopark.

From a geoeducational point of view the 641 AD eruption site is also ideal. Each of the cones and their volcanic features can be linked directly to volcanic heritage sites in other parts of the HAMVG (Fig. 5). The 641 AD eruption site is a perfect reflection of the volcanic features spread across the HAMVG and therefore could be a perfect initial point for anyone wishing to visit and explore the geopark (Fig. 5). In fact, it would be advisable for all future visitors to be recommended to start their adventure in this site. From a scientific point of view, the 641 AD eruption site can follow a logical path to guide the visitors toward the more distant locations that are part of the precincts defined in the HAMVG's distal zones (Fig. 5). Ideally the 641 AD eruption site could be designed to be a geoeducational center through geopaths that would offer the visitor similar features that could be seen if they decided to visit the other sites in the HAMVG. Such study paths could be arranged following the precinct concept designed for the whole AMVG [9], allowing the visitors to become familiar with the knowledge they could gain and become prepared for further exploration of the full extent of the precincts of the HAMVG.

Study path 1 would prepare the visitor for the youngest volcanic eruptions of the AMVF and could be linked to Precint 1's geosites (Figs. 3, 5A). To complete Study path 1 would involve a visit to a visitor center (or public access point) where basic volcanic features, rocks and copies of historic documents would be exhibited, as well as a short walk to the top of cone 3 to allow the visitors to admire the view of Al Madinah city and the location of the 641 AD cones. Study path 2 would take the visitors to the top and around cone 4 to see the results of lava fountaining, lava flow initiation, as well as partial cone rafting (Fig. 3). In this sense Study path 2 could be logically linked to the geoheritage and geotourism concepts of the whole of Precincts 1 and 2 (Fig. 5A, B). To complete the view, visitors could continue the walking tracks along Study path 3 to see the basal tuff ring sections, the steep but small lava spine on cone 3 and get an introduction to what they would be able to explore if they were to visit the geosites of Precinct 3 (Figs. 3, 5C).

In the visitor center (main access point), as well as information leaflets and information boards, the selected geosites at the $641 \mathrm{AD}$ eruption site could be linked not only to other geosites located in the relevant precincts of the
HAMVG, but also to similar volcanic features protected elsewhere. This step would certainly facilitate the connection of the HAMVG to other similar geoparks on Earth, and would serve as an important step to actively link the geopark to the global network of similar geoparks, not only through official geopark networks [47] but also via the potential visitors. The $641 \mathrm{AD}$ eruption site is an important geoheritage site that is not only unique in geological terms, but is also linked to the rich cultural heritage of Al Madinah city, providing a complex geoheritage site with great geodiversity which is proposed in other cases as a desired goal of such projects [14].

\section{THE ROLE OF AN ESTABLISHMENT OF A VISITOR CENTER}

The $641 \mathrm{AD}$ eruption site is located in an easy to access part of the SW suburban area of Al Madinah city with good infrastructure. Around the site there is enough free space to expand car parks, or other amenities including shops, memorabilia stalls and toilet facilities (Fig. 3). The four cones are surrounded by sealed roads that are directly connected to the main motorway entering Al Madinah city from the coastal port of Jeddah (Fig. 1). To establish an educational center in this location is an important step in establishing and turning the HAMVG in to a fully functional geopark. A visitor center could show a basic, but fundamental, collection of rocks, maps, historic documents (including photos) and substantial information linking this information to the global network of knowledge on the volcanism of the AMVF (eg. photos of recent volcanic eruptions that formed volcanic landforms similar to those abundant in the AMVF). A visitor center could in this way also function as a significant educational center where basic volcanic knowledge could be transferred to the general public, as well as to be a hub to offer recreational programs to visitors [48]. A visitor center could function in multiple languages, attracting all visitors to the region, from religious pilgrims to casual visitors. In addition the visitor center could cater for casual visits from the local communities, as well as schools. In this aspect, a visitor center could function as a significant messenger for the transmission of geological knowledge to the local young generations. Similar educational centers function very well elsewhere, and many of them are deeply embedded in the educational programs of local schools, or recreational programs offered by local tour operators. The visitor center is also designed as a starting point to explore both the $641 \mathrm{AD}$ eruption site, as well as the whole HAMVG. Extensive usage should be made of information boards, leaflets and 3D models, as described in many other geopark projects $[49,50]$ and there should be regular training for local tour guides and school teachers [51]. The visitor center, due to its central location and proximity to Al Madinah city, is planned to function as a research center where a gradual collection of visitor and user information, opinions and suggestions could be collected, researched and archived [52, 53]. The educational program of the visitor center and the entire HAMVG can be designed in a way to maximize its benefits to provide a holistic view to nature that can serve educational programs reaching beyond the pure geoconservation or geoheritage [54]. 


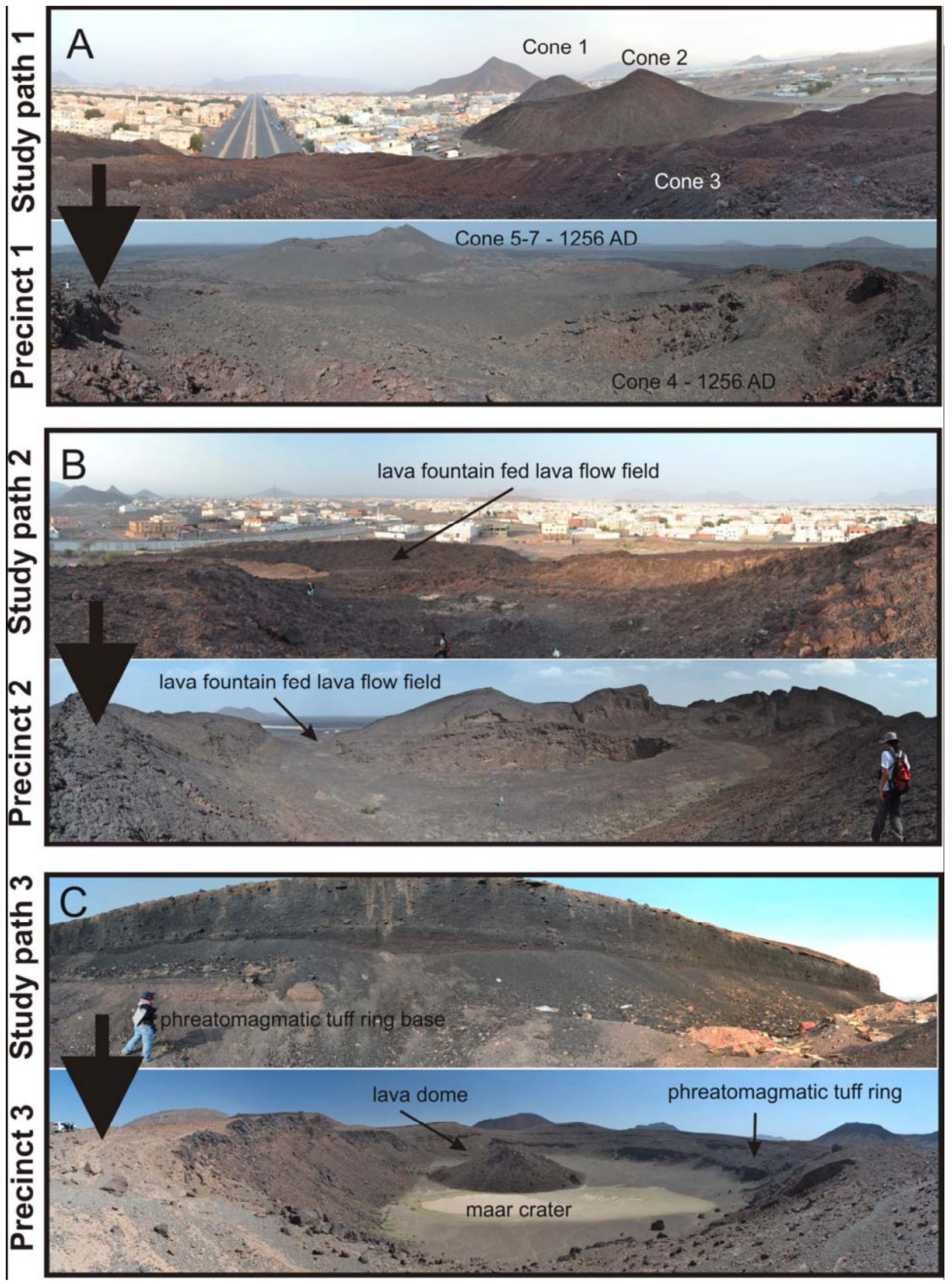

Fig. (5). Photo pairs of sites of the 641 AD eruption site and their link to the Harrat Al Madinah Volcanic Geopark's precints. (A) Upper view represents scoria cones similar but smaller to those ready to be studied at the 1256 AD eruption site. (B) Cone 4 of the 641 AD volcanic chain is a good example for see results of lava fountaining in smaller scale as it can be seen in the Harrat Al Madinah Volcanic Geopark's Precinct 2 (lower image). (C) Evidences of mild phreatomagmatism are evident at three cones of the 641 AD eruption site, that are smaller in scale than those can be seen at the Harrat Al Madinah Volcanic Geopark's Precinct 3 (lower image). 


\section{TOURISM AND TOURISTIC DEMAND: A PRELIMINARY ASSESMENT FOR AL MADINAH}

Al Madinah city is the capital of Al Madinah Province. The Al Madinah Province stretches from the Red Sea coastline deep inland to the eastern boundary of the Harrat Rahat (Fig. 1) and hosts numerous natural wonderlands, including the majority of the Al Madinah Volcanic Field, as well as another volcanic field (Harrat Khyber) just north of the city. Al Madinah city is linked by a motorway to the Red Sea port of Jeddah, as well as toward to east to the capital of the Kingdom, Riyadh. The infrastructure of the city is well developed through wide streets and a well-maintained network of motorways, allowing easy access to every part of the urban area. Non-Muslims are not allowed to enter to the city center, which is marked by an outer ring motorway, making it easy to cross the city without entering its downtown region. The city's population is about 1.5 million, and it is one of the main cultural and religious centers for the Muslim world. The city's current development includes developing a so called "Knowledge Economy City" close to a transportation hub which is designed in the vicinity of the international airport, connecting high-speed train and longdistance bus networks in the near future (http://www.madinahkec.com/). This project is expected to be completed around 2015-16, making Al Madinah a significant regional and international transportation, cultural, educational and economical centre. The completion of the "Knowledge Economy City" would involve the establishment of university campuses, high-tech company headquarters, as well as various exhibition centers. Such a project naturally implies that the inflow of highly educated and economically well-off population growth is expected, which will provide demand of extra touristic activity, potentially including engagements with geoheritage and geopark programs.

The main tourism of the city is based on various religious activitities, including the yearly Hajj with an estimated $1-4$ million local and foreign visitors annually [55]. Tourism is now the third largest industry in the Kingdom after energy and manufacturing and is considered to be the second largest provider of foreign exchange, as well as a job creating sector [56]. These recent figures explain that there is great official interest in the tourism industry of the Kingdom, including some preliminary measures for its development, such as collecting data of tourist activities or types of business region by region. Naturally the Kingdom is attracting mostly Muslim visitors, and the majority of the foreign Muslim visitors go to engage in religious activities (Fig. 6). Interestingly, a detailed study conducted by the Tourist Information and Research Centre (http://www.mas.gov.sa) has shown some surprising data highlighting that large numbers of tourist engage in some sort of cultural (nonreligious), natural environmental or outdoor activities (Figs. $\mathbf{6}, \mathbf{7}$ ), indicating that there is an increasing interest from visitors to see and visit natural heritage sites, such as national parks, mountainous areas, reserves or just explore the natural and cultural environment. Such trends are a clear sign that there is plenty of room to develop projects involving visiting geoconservation areas or geoparks in the Kingdom. Geoconservation areas and geoparks are the perfect avenues to capture visitors' attention if they are welldesigned and embedded in the local community, as well as promoted with the right tone to the general public (including local and international visitors) [29, 31, 57, 58]. Recent studies demonstrated that Saudi Arabia is viewed as a unique tourist destination; however, its potential is underutilized [56]. Interestingly but not unexpectedly a study also showed that Saudi Arabia is not expected to be a major international tourist destination in spite of the numerous natural wonders the country offers [56]. To break this preconception, geoparks and geoconservation sites, with aided high quality programs and supporting facilities, could play a major role. The volcanic fields of western Saudi Arabia, such as the Al Madinah Volcanic Field, therefore, should be looked at with special care. The location of the volcanic field, in the proximity of the culturally and religiously significant city of Al Madinah, makes the proposed Harrat Al Madinah Volcanic Geopark [9] a viable and provisionally successful idea. A gateway point in the form ofthe $641 \mathrm{AD}$ historic eruption sites in the urban area of the city would likely develop in to a major tourist attraction that should be considered seriously. We also have to mention future work to collect exact and measurable data on the effectiveness of any geoconservation projects planned in the Al Madinah Volcanic Field. Some recent studies highlighted that the success of a geoconsevation project, including geoparks, strongly depend on narrow the gap between the scientific view of the values of the region and the local population's prevailing view of geological and geomorphological heritage values, as well as diversities [14]. In a simplistic way, an expert can define geological and geomorphological diversity in a very different way from how a local person and/or a visitor would define it [14]. To accommodate this difference in potential "worldview" in the geoheritage projects, such as the $641 \mathrm{AD}$ eruption site development, either time and energy needs to be invested to educate the general public and/or to conduct surveys to see clearly the view of the public on their geoheritage and then to merge these two concepts into a viable project [14]. So far such studies or programs have not been conducted, but they are in the draft stages and results will be available in the near future.

\section{CONCLUSION}

The $641 \mathrm{AD}$ historic eruption site is a significant geological heritage site that is located in the urban area of one of the most holy cities for Muslims, Al Madinah. The four cones produced by the $641 \mathrm{AD}$ eruption are typical lava spatter and scoria cones formed by relatively mild explosive volcanic eruptions that also produced short lava flows. Each of the volcanic cones are relatively small and easy to access from the city, making this location a perfect site to establish a geoeducation center that could function as a gateway to the earlier proposed Harrat Al Madinah Volcanic Geopark. The volcanic rocks and landforms preserved in this easy to access site have significant aesthetic value that should be preserved. This is also justified by the fact that these volcanoes host nearly every geological feature that can be identified in the whole area of the Al Madinah Volcanic Field. This concentrated nature of volcanic features that can be seen in this location in a very small area provides a perfect, didactically correct foundation to develop a geoeducation program that can be viewed as an introduction to the entire volcanic field. The urban location of the $641 \mathrm{AD}$ cones also can capture tourists with relatively low interest in volcanic 


\section{Al Madinah Province $\square$ Al Madinah City}
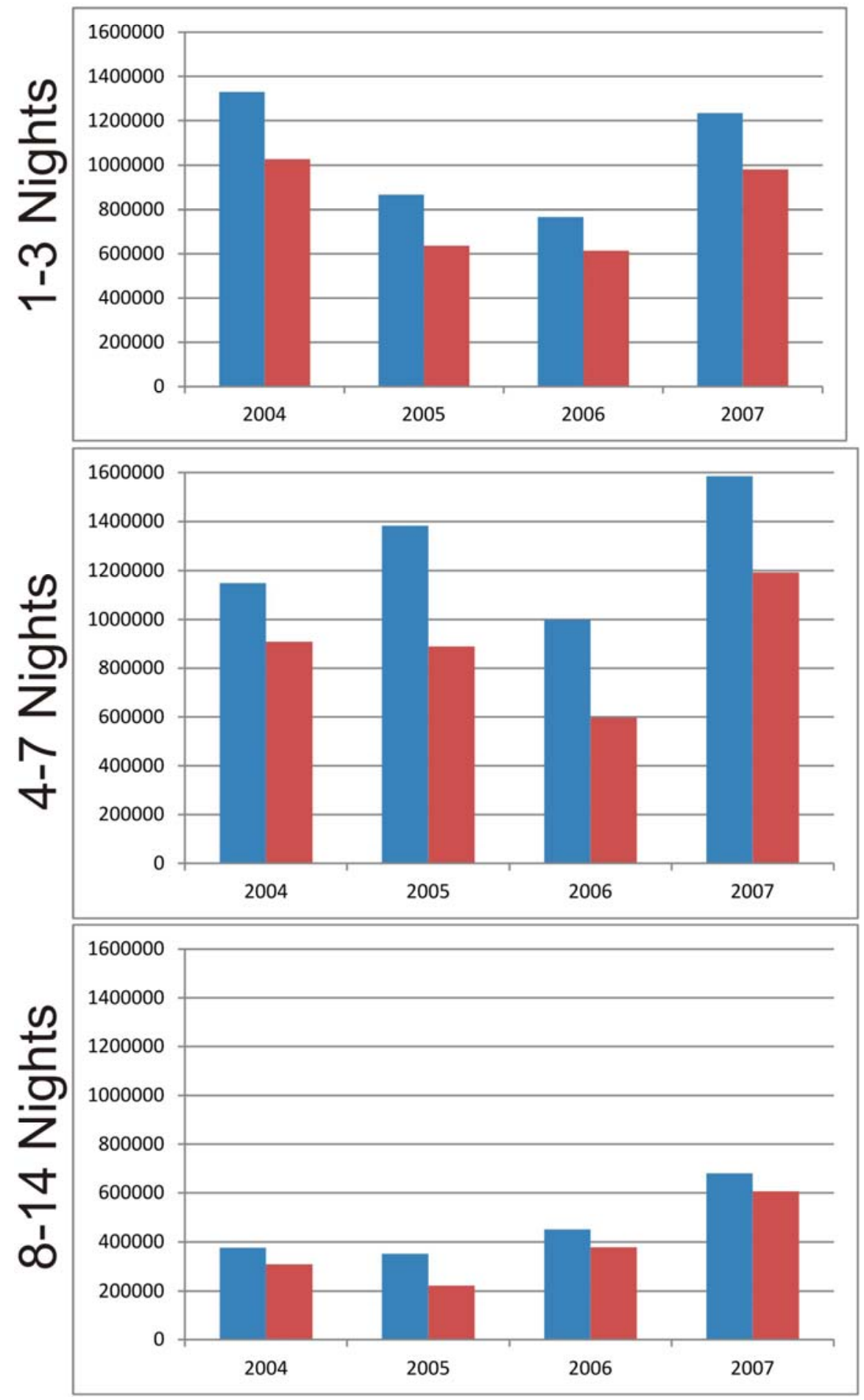

Fig. (6). Guest nights spent in the region.

geology, as well as to provide basic information for those planning more adventure-like tourism in the Harrat $\mathrm{Al}$ Madinah. It has also been demonstrated that the geoeducational program proposed for the Harrat $\mathrm{Al}$ Madinah Volcanic Geopark as the fundamental basis of the geotourism in the region can be aligned with the geoeducational program the $641 \mathrm{AD}$ volcanic cones can offer through their volcanic heritage.

\section{CONFLICT OF INTEREST}

The authors confirm that this article content has no conflict of interest.

\section{ACKNOWLEDGEMENTS}

This report is based on new research results to evaluate the volcanic geoheritage in the Kingdom of Saudia Arabia. 

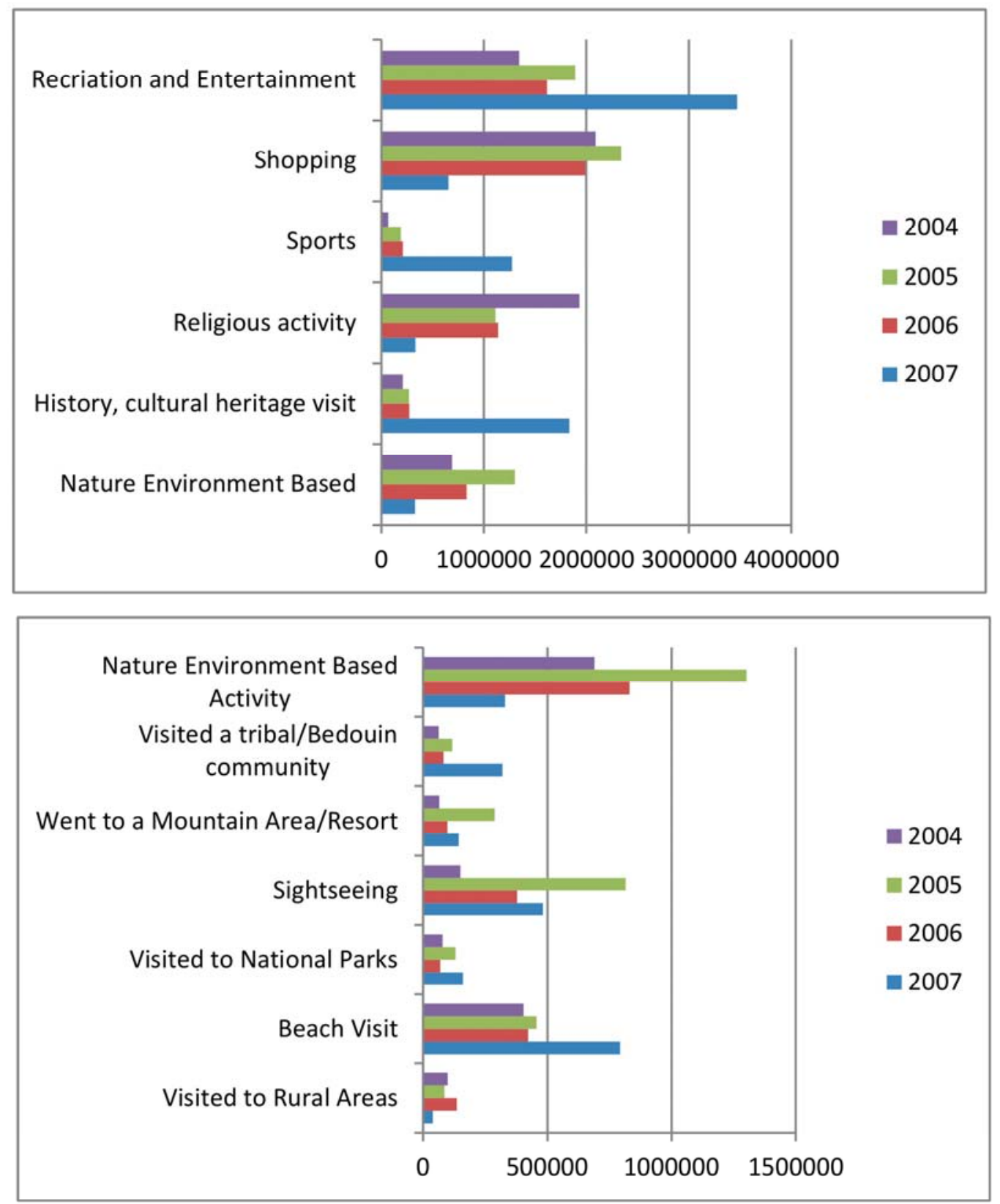

Fig. (7). Various activities in what visitors were involved in Saudi Arabia.

Critical comments from Dr. Corina Risso and an Anonymous Journal reviewer made this paper more valuable. Comments and suggestions by Dr. Kate Arentsen have also helped significantly to shape this manuscript to be a reader-friendly paper.

\section{REFERENCES}

[1] Jonsson S, Pallister J, McCausland W, El-Hadidy S. Dyke intrusion and arrest in Harrat Lunayyir, western Saudi Arabia, in April-July 2009. Geophys Res Abstr 2010; 12: EGU2010-7704.

[2] Zahran HM, McCausland WA, Pallister JS, et al. Stalled eruption or dike intrusion at Harrat Lunayyir, Saudi Arabia? Eos 2009; 90: Abstract V13E-2072.

[3] Moufti MR, Hashad MH. Volcanic hazards assessment of Saudi Arabian Harrats: geochemical and isotopic studies of selected areas of active Makkah-Madinah-Nafud (MMN) volcanic rocks. Final project Report (LGP-5-27) 679, Riyadh, Saudi Arabia: submitted to King Abdulaziz City for Science and Technology 2005; pp. 1-401.
[4] Moufti MR, Matsah MI, Soliman MA, Moghazi AM. Arabian plume dynamics beneath Al-Madinah Al-Munawwarah region and its related geohazards. Final project Report (ARP-26-79), Riyadh, Saudi Arabia: submitted to King Abdulaziz City for Science and Technology 2011; pp. 1-382.

[5] Moufti MR, Moghazi AM, Ali KA. Geochemistry and Sr-Nd-Pb isotopic composition of the Harrat Al-Madinah Volcanic Field, Saudi Arabia. Gondwana Res 2012; 21: 670-89.

[6] Moufti MR, Moghazi AM, Ali KA. 40Ar/39Ar geochronology of the Neogene-Quaternary Harrat Al-Madinah intercontinental Volcanic Field, Saudi Arabia: implications for duration and migration of volcanic activity. J Asian Earth Sci 2012; 62: 253-68.

[7] Moufti RM, Németh K, Murcia H, Lindsay J, El-Masry N. Geosite of a steep lava spatter cone of the $1256 \mathrm{AD}, \mathrm{Al}$ Madinah eruption, Kingdom of Saudi Arabia. Cen Eur J Geosci 2013; 5 (2): 189-95.

[8] Moufti MR, Németh K, El-Masry N, Qaddah A. Geoheritage values of one of the largest maar craters in the Arabian Peninsula: the Al Wahbah Crater and other volcanoes (Harrat Kishb, Saudi Arabia). Cen Eur J Geosci 2013; 5 (2): 254-71. 
[9] Moufti MR, Németh K. The intra-continental Harrat Al Madinah Volcanic Field, Western Saudi Arabia: a proposal to establish Harrat Al Madinah as the first volcanic geopark in the Kingdom of Saudi Arabia. Geoheritage 2013 [in press]:

[10] Joyce E. Australia's Geoheritage: History of Study, A New Inventory of Geosites and Applications to Geotourism and Geoparks. Geoheritage 2010; 2: 39-56.

[11] Huang S. The geological heritages in Xinjiang, China: Its features and protection. J Geogr Sci 2010; 20: 357-74.

[12] Deraman A, Yahaya JH, Salim J, et al. A Geodiversity Repository System Based on Digital Object Modeling: An Applied Research on Langkawi Geoparks. In: Soliman KS, Ed. Knowledge Management and Innovation: A Business Competitive Edge Perspective. 2010; vols 1-3. pp. 1208-17.

[13] Prosser CD. Our rich and varied geoconservation portfolio: the foundation for the future. Proceedings of the Geologists Association 2013 [in press].

[14] Erikstad L. Geoheritage and geodiversity management - the questions for tomorrow. Proceedings of the Geologists Association 2013 [in press].

[15] Wehr H. A dictionary of modern written Arabic [An enlarged and improved version of 'Arabisches Wörterbuch für die Schriftsprache der Gegenwart' and includes the Contents of the 'Supplement zum Arabischen Wörterbuch für die Schriftsprache der Gegenwart by Otto Harrauowltz, Wiesbaden 1961, 1966, 1971]. Spoken Language Services, Inc.: New York 1976.

[16] Camp VE, Roobol MJ. The Arabian Continental Alkali Basalt Province .1. Evolution Of Harrat-Rahat, Rahat, Kingdom-OfSaudi-Arabia. Geol Soc of Am Bull 1989; 101: 71-95.

[17] Camp VE, Hooper PR, Roobol MJ, White DL. The Madinah eruption, Saudi Arabia: Magma mixing and simultaneous extrusion of three basaltic chemical types. Bull Volcanol 1987; 49: 489-508.

[18] Valentine GA, Gregg TKP. Continental basaltic volcanoes Processes and problems. J Volcanol Geotherm Res 2008; 177: 85773.

[19] Walker GPL. Basaltic-volcano systems. In: Prichard HM, Alabaster T, Harris NBW, Nearly CR, Eds. Magmatic Processes and Plate Tectonics. Soc, London: Spec Publications 1993; pp. 3-38

[20] Connor CB, Conway FM. Basaltic volcanic fields. In: Sigurdsson H, Ed. Encyclopedia of Volcanoes. San Diego: Academic Press 2000; pp. 331-43.

[21] Németh K. Monogenetic volcanic fields: Origin, sedimentary record, and relationship with polygenetic volcanism. In: CanonTapia E, Szakacs A, Eds. What Is a Volcano? USA: Geol Soc Am (spec pap) 2010; vol. 407: pp. 43-66.

[22] Németh K, Haller MJ, Siebe C. Maars and scoria cones: the enigma of monogenetic volcanic fields. J Volcanol Geotherm Res 2011; 201: V-Viii.

[23] Martin U, Németh K, Lorenz V, White JDL. Introduction: Maardiatreme volcanism. J Volcanol Geotherm Res 2007; 159: 1-3.

[24] Armiero V, Petrosino P, Lirer L, Alberico I. The GeoCaF Project: Proposal of a Geosites Network at Campi Flegrei (Southern Italy). Geoheritage 2011; 3: 195-219.

[25] Camp VE, Roobol MJ, Hooper PR. The Arabian Continental Alkali Basalt Province .3. Evolution of Harrat Kishb, Kingdom of SaudiArabia. Geolo Soc Ame Bull 1992; 104: 379-96.

[26] Camp VE, Roobol MJ, Hooper PR. The Arabian Continental Alkali Basalt Province .2. Evolution of Harrats Khaybar, Ithnayn, and Kura, Kingdom of Saudi-Arabia. Geolo Soc Ame Bull 1991; 103: 363-91.

[27] Dubray EA, Stoeser DB, McKee EH. Age and Petrology of the Tertiary as-Sarat Volcanic Field, Southwestern Saudi-Arabia. Tectonophysics 1991; 198: 155-80.

[28] Camp VE, Roobol MJ.Upwelling asthenosphere beneath Western Arabia and its regional implications. J Geophys Res Solid Earth 97(B11): 15255-71.

[29] Farsani NT, Coelho C, Costa C. Geotourism and Geoparks as Gateways to Socio-cultural Sustainability in Qeshm Rural Areas, Iran. Asia Pac J Tourism Res 2012; 17: 30-48.

[30] Kazancı N. Geological Background and Three Vulnerable Geosites of the Kızılcahamam-Çamlidere Geopark Project in Ankara, Turkey. Geoheritage 2012; 4: 249-61.

[31] Ghazi J, Ólafsdóttir R, Tongkul F, Ghazi J. Geological Features for Geotourism in the Western Part of Sahand Volcano, NW Iran. Geoheritage 2013; 5: 23-34.
[32] Yolal M. Geotourism and geoparks: the case of KizilcahamamCamlidere Geopark. Geo J Tourism Geosites 2012; 10: 193-203.

[33] Martín-Duque J, Caballero García J, Carcavilla Urquí L. Geoheritage Information for Geoconservation and Geotourism Through the Categorization of Landforms in a Karstic Landscape. A Case Study from Covalagua and Las Tuerces (Palencia, Spain). Geoheritage 2012; 4: 93-108.

[34] Farsani NT, Coelho C, Costa C. Geotourism and Geoparks as Novel Strategies for Socio-economic Development in Rural Areas. Int J Tourism Res 2011; 13: 68-81.

[35] Fuertes-Gutierrez I, Fernandez-Martinez E. Mapping Geosites for Geoheritage Management: A Methodological Proposal for the Regional Park of Picos de Europa (Leon, Spain). Environ Manag 2012; 50: 789-806.

[36] Henriques MH, dos Reis RP, Brilha J, Mota T. Geoconservation as an emerging geoscience. Geoheritage 2011; 1-12.

[37] Fassoulas C, Mouriki D, Dimitriou-Nikolakis P, Iliopoulos G. Quantitative assessment of geotopes as an effective tool for geoheritage management. Geoheritage 2011; 1-17.

[38] Al-Samhoody NAA. Wafa Al-Wafa Bi-Akhbar DarAl-Mustafa. Reprinted (1955) By Mohammad Mohiuddin Abdul Hamid with comments. Beirut Lebanon: Dar Al-Ahya Al-Sarawat Al-Gharbi, 1440-1506 A.D 1995; pp.1-776.

[39] Camp VE, Roobol MJ. The Arabian continental alkali basalt province; Part I, Evolution of Harrat Rahat, Kingdom of Saudi Arabia; with Suppl. Data 89-04. Geol Soc Am Bull 1989; 101: 7195.

[40] Kereszturi G, Jordan G, Németh K, Doniz-Paez JF. Syn-eruptive morphometric variability of monogenetic scoria cones. Bull Volcanol 2012; 74: 2171-85.

[41] Kereszturi G, Németh K. Monogenetic basaltic volcanoes: genetic classification, growth, geomorphology and degradation. In: Németh $\mathrm{K}$, Ed. Updates in Volcanology - New Advances in Understanding Volcanic Systems. Rijeka, Croatia: inTech Open 2012; pp. 3-88.

[42] Lorenz V. Phreatomagmatism and its relevance. Chem Geol 1987; 62: 149-56.

[43] Lorenz V. On the growth of maars and diatremes and its relevance to the formation of tuff rings. Bull Volcanol 1986; 48: 265-74.

[44] Rosseel JB, White JDL, Houghton BF. Complex bombs of phreatomagmatic eruptions: Role of agglomeration and welding in vents of the 1886 Rotomahana eruption, Tarawera, New Zealand. J Geophys Res 2006; 111: B 12205.

[45] Sottili G, Taddeucci J, Palladino DM. Constraints on magma-wall rock thermal interaction during explosive eruptions from textural anal of cored bombs. J Volcanol Geotherm Res 2010; 192: 27-34.

[46] Houghton BF, Schmincke HU. Rothenberg scoria cone, East Eifel; a complex strombolian and phreatomagmatic volcano. Bull Volcanol 1989; 52: 28-48.

[47] Farsani NT, Coelho COA, C.M.M. C. Analysis of network activities in geoparks as geotourism destinations. Int J Tourism Res 2012; [in press]

[48] Azman N, Halim SA, Liu OP, Saidin S, Komoo I. Public Education in Heritage Conservation for Geopark Community. In: Jelas ZM, Salleh A, Azman N, Eds. International Conference on Learner Diversity. ICELD. Bangi; Malaysia 2010; pp. 504-11.

[49] Sakiyama T, Matsubara N. Educational programs using topographic models for understanding the geology and land use of the volcanic area in San-in Kaigan Geopark, Japan; communicating geology. Geology (Vietnam) 2011; 37-38: 70-2.

[50] Bitschene P, Schueller A. Geo-education and geopark implementation in the Vulkaneifel European Geopark. GSA Field Guide 2011; 22: 29-34.

[51] Guo J, Tian MZ, Yang J, Zhang HZ. The Training and Management of Tour Guides in Geopark. In: Hu QM, Ed. International Conference on Education Science and Management Engineering 2011; pp. 1613-7.

[52] Azman N, Halim SA, Liu OP, Komoo I. The Langkawi Global Geopark: local community's perspectives on public education. Int J Herit Stud 2011; 17: 261-79.

[53] Fang SM, Li JF, Zhang J, Chang DF. The theory and method research on the geopark information system building. In: Zhao $\mathrm{P}$, Agterberg F, Cheng Q, Eds. Proceedings of the IAMG '07: Geomathematics and GIS Analysis of Resources, Environment and Hazards. 2007; pp. 767-72.

[54] Nemeth K, Martin U. Pedagogical and didactical methods in the Geopark concept in the demonstration of volcanic processes 
associated with monogenetic volcanic fields in Hungary; the Montessori method as a viable alternative. Occasional Papers of the Geological Institute of Hungary 2004; 203: 80

[55] Henderson JC. Religious Tourism and Its Management: The Hajj in Saudi Arabia. Int J Tourism Res 2011; 13: 541-52.

[56] Sadi AM, Henderson JC. Tourism in Saudi Arabia and its future development. J Bus Econ 2005; 11: 94-111.
[57] Hose TA, Vasiljević DA. Defining the Nature and Purpose of Modern Geotourism with Particular Reference to the United Kingdom and South-East Europe. Geoheritage 2012; pp. 1-19.

[58] Fernandez MP, Timon DL, Marin RG. Geotorusim as a development strategy in deprived rural areas: proposal of Villuercas Geoparks, Ibores, Jara (Extremadura). Bol Aso Geog Espanoles 2011; 485-97.

Received: April 15, 2013

Revised: June 7, 2013

Accepted: June 23, 2013

(C) Moufti et al; Licensee Bentham Open.

This is an open access article licensed under the terms of the Creative Commons Attribution Non-Commercial License (http://creativecommons.org/licenses/by$\mathrm{nc} / 3.0 /$ ) which permits unrestricted, non-commercial use, distribution and reproduction in any medium, provided the work is properly cited. 